\title{
糖尿病性腎不全による透析患者の味覚障害と塩分，水分管理
}

\author{
金澤良枝小倉誠岡田知也高橋創 \\ 韓 明 基 中尾 俊之 \\ 東京医科大学腎臓科
}

key words : 糖尿病性腎不全, 透析患者, 味覚障害, 塩分水分

〈要旨〉

糖尿病性腎不全透析患者に定量的味覚調査を行い塩分味覚障害を明らかにした。さらに定期的食事指導下におけ る, 塩分, 水分管理状況を明らかにし, 塩分味覚障害との関連性および血糖コントロールとの関連性について検討 した.

対象は, 糖尿病性腎不全による透析患者 26名（血液透析：DM-HD 21 名, CAPD：DM-CAPD 5名）平均年齢 $54.3 \pm 8.4$ 歳である. 対象者に全口腔法による味覚調査を行い, 非糖尿病透析患者および健常者を対照とし比較し た。 また対象者のうち 18 名で塩分および水分㩒取量調查を行った。

糖尿病透析患者の味覚感知濃度は $22.8 \pm 13.2 \mathrm{mmol} / l$, 塩分認知濃度は $33.7 \pm 10.8 \mathrm{mmol} / l$ で対照群に比べ有 意 $(p<0.001)$ に悪かった. 塩分認知濃度と 1 日の塩分振取量および水分㩒取量とは，相関関係を認めなかった。 DM-HD, DM-CAPD の 1 日水分摂取量は塩分摄取量と相関関係 $(\mathrm{p}<0.001)$ を認めた。しかし, HbA1c とは相関 関係を認めず DM-HD の透析前血糖值とも相関関係を認めなかった。

以上より, 糖尿病透析患者では塩分味覚が非糖尿病透析患者より有意に悪かったが, 味覚障害が必ずしも塩分摂 取量の過剩に結びつくとは限らないと考えられた。糖尿病透析患者の水分㩒取量は塩分㩒取量の多少により規定さ れ血糖コントロールの影響は少ないことが示唆された. 本症患者の塩分, 水分管理において味覚障害の程度を把握 することは，食事指導上の意義が大きいと考えられた。

\section{Taste acuity and control of salt and water intake in diabetic dialysis patients}

Yoshie Kanazawa, Makoto Ogura, Tomonari Okada, Hajime Takahashi, Mingi Han, Toshiyuki Nakao Department of Nephrology, Tokyo Medical University

The thresholds of taste detection and recognition of saltiness were determined in 26 diabetic dialysis patients (mean age $54.3 \pm 8.4$ years), by placing a test solution in the mouth for 5 seconds, and the results were compared with those of age-and sex-matched healthy controls and 58 non-diabetic dialysis patients. The daily salt and water intakes of diabetic dialysis patients were calculated, and the relationship between their intake and either taste acuity regarding saltiness and glycemic control was investigated.

The mean thresholds of taste detection and recognition in diabetic dialysis patients were $22.8 \pm 13.2 \mathrm{mmol} /$ $l$ and $33.7 \pm 10.8 \mathrm{mmol} / l$, respectively, values which were significantly higher than in both healthy controls and non-diabetic dialysis patients $(p<0.001)$. No correlation between recognition of saltiness and daily intake either of salt or water was observed. Water intake correlated significantly with salt intake $(p<0.001)$, but no correlation was found between daily water intake and either $\mathrm{HbA1c}$ or blood glucose levels.

These results show that diminished acuity, with regard to saltiness, in diabetic dialysis patients does not

金澤 良枝 東京医科大学腎臓科干１60 新宿区西新宿 6-7-1 (03-3342-6111)

〔受付: 平成 6 年 10 月 20 日, 受理 : 平成 7 年 3 月 3 日〕 
necessarily contribute to excess intake of salt and water, and that water intake is controlled mostly by salt intake rather than by blood glucose levels. In conclusion, knowing the extent of diminished taste acuity might be valuable in diet education aimed at modifying salt and water intakes.

\section{緒言}

透析患者の食事療法に扔いては，塩分，水分管 理は基本的でかつ重要な事項である。また透析患 者では，健常者に比較し味覚障害が高度であると 報告1 4)されている.しかし,この味覚障害による 塩分の認知不良と, 塩分摂取過剩ひいて証水分管 理不良の関連性について検討した報告はない。ま た糖尿病性腎不全による透析患者の塩分味覚障害 に対する報告も殆どされていないのが現状であ 子.

今回我久は，糖尿病性腎不全による透析患者の 味覚障害を明らかにする目的で，塩分味覚調查を 定量的に行った。ささらに定期的食事指導下におけ る, 塩分水分管理状況を明らかにし, 塩分味覚障 害との関連性および血糖コントロールとの関連に ついて検討したので報告する。

\section{方法}

対象は, 糖尿病性腎不全による透析患者 26 名 (HD 21 名, CAPD 5 名), 平均年齢 $54.3 \pm 8.4$ 歳 である。対象者に塩分味覚調査を行い，年齚，性 別を一致させた非糖尿病透析患者 58 名（HD 50 名, CAPD 8 名, 平均年齢 $51.2 \pm 10.7$ 歳)おるび 健常者 16 名（平均年齢 $51.8 \pm 11.5$ 歳）と比較し た.

塩分味覚調查は全口腔法にて行った。本法では, 塩化ナトリウム $0 \mathrm{mmol} / l$ から $50 \mathrm{mmol} / l$ まで $2.5 \mathrm{mmol} / l$ 毎に, 21 種類の溶液を作成して用い た. RO 水 (reverse osmosis) で含嗽を行った後, $0 \mathrm{mmol} / l$ から順番に $15 \mathrm{~m} l$ ずつ口に 5 秒間含み 吐き出して, 各濃度につき味覚感知の有無および 感知味覚の種類を調查した。次の濃度の溶液に移 る時はその都度 $\mathrm{RO}$ 水で含嗽を行った，味の異常 を感じた濃度を味覚感知濃度, 塩分を感じた濃度 を塩分認知濃度とした。検査前 1 時間は絶食, 禁 煙とした。

また，血液透析例では血中亜鉛濃度を測定した。 さらに対象者のうち, 血液透析患者 (DM-HD) 13
名, 同 CAPD 患者 (DM-CAPD) 5 名にて塩分, 水分摂取量調查抢よび HbA1c, HD 前血糖値を測 定した。対象症例では全例 1 か月に 1 回定期的に 食事指導を行って扔り，その塩分指示量は HD 患

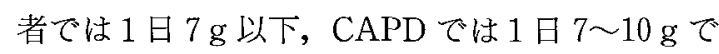
ある。

塩分摂取量は DM-HD では木村)の方法によ り, 非透析日の 2 日間の透析間 $\mathrm{Na}$ 蓄積量を求め, これに 1 日尿量 $\times$ 尿 $\mathrm{Na}$ 濃度を加算して, 下記に より算出した.

塩分恸取量 $=$ (透析間 $\mathrm{Na}$ 蓄積量 $(\mathrm{mEq}) / 3+$ 1 日尿中 $\mathrm{Na}$ 排泄量 $(\mathrm{mEq})) / 17$

CAPD では 1 日総除水量 $\times$ 排液 $\mathrm{Na}$ 濃度を求 め, これに 1 日尿量 $\times$ 尿 $\mathrm{Na}$ 濃度を加算して, $\mathrm{Na}$ 除去必要量として下記により算出した.

塩分摂取量 $=($ 排液中 $\mathrm{Na}$ 濃度 $(\mathrm{mEq}) \times$ 除水 量 +1 日尿中 $\mathrm{Na}$ 排泄量 $(\mathrm{mEq})) / 17$

水分摂取量は, HDでは 1 日当たりの透析間体 重増加量に 1 日尿量および不感蒸泄量を加えて算 出した. CAPDでは体重変化のない時期の 1 日総 除水量抢よび不感蒸泄量に 1 日尿量を加えて水除 去必要量より算出した。不感蒸泄量は基本体重 $\times$ $15 \mathrm{~m} l$ で算出した6).

\section{結果}

糖尿病透析患者の味覚感知濃度は $22.8 \pm 13.2$ $\mathrm{mmol} / l$ に対し, 非糖尿病例 $10.0 \pm 6.3 \mathrm{mmol} / l$, 健 常者 $6.1 \pm 2.4 \mathrm{mmol} / l$ であった.また，塩分感知 濃度は糖尿病例 $33.7 \pm 10.8 \mathrm{mmol} / l$ に対し, 非糖 尿病例 $20.0 \pm 9.4 \mathrm{mmol} / l$, 健常者 $9.4 \pm 5.0 \mathrm{mmol} /$ $l$ であった。糖尿病透析患者では味覚感知濃度, 塩 分認知濃度とも非糖尿病例, 健常者に比較し有意 $(\mathrm{p}<0.001)$ に高かった（図 1). DM-HD 例の血 中覀鉛濃度は $67.2 \pm 8.4 \mu \mathrm{g} / \mathrm{d} l$ で, 非糖尿病 HD 例 $65.6 \pm 10.8 \mu \mathrm{g} / \mathrm{d} l$ とは有意差を認めなかった (正常域は 65〜 $110 \mu \mathrm{g} / \mathrm{d} l$ ).

塩分摄取量は DM-HD $10.4 \pm 6.5 \mathrm{~g} /$ 日, DMCAPD $7.1 \pm 2.6 \mathrm{~g} /$ 日であった。 また水分摂取量は 


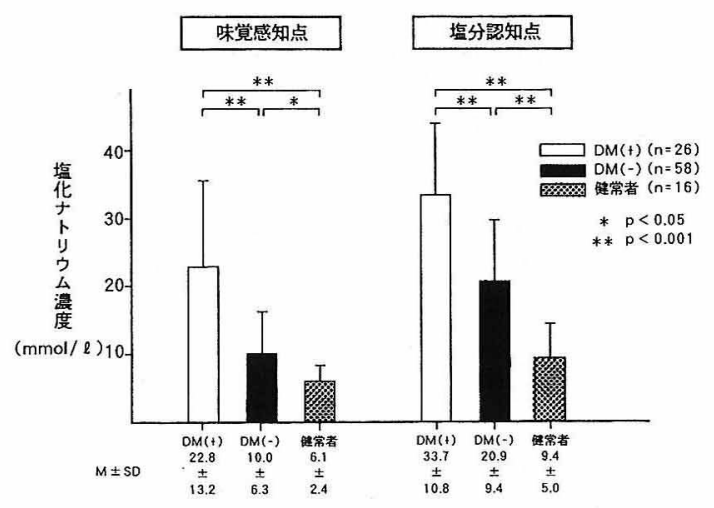

図 1 糖尿病性腎不全透析患者に対する味覚検査 での味覚感知点と塩分認知点（非糖尿病例 との比較)

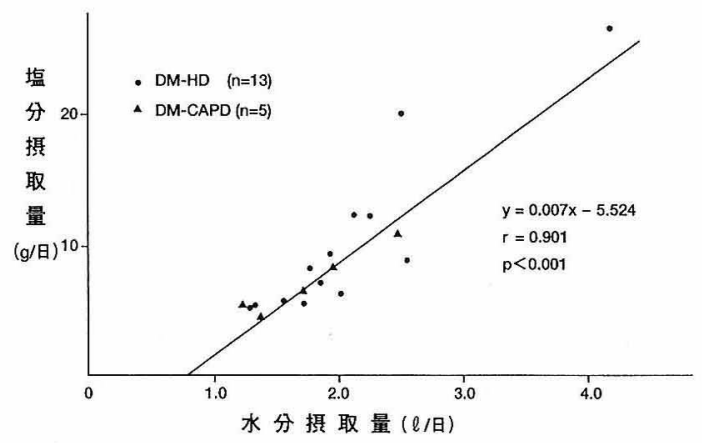

図 2 糖尿病性腎不全透析患者 $(n=18)$ におけ る水分摂取量と塩分摂取量との関係

DM-HD $2.10 \pm 0.79 l /$ 日，DM-CAPD $1.78 \pm 0.48$ l/日であった. DM-HD, DM-CAPD の 1 日水分 摄取量と塩分摈取量は有意 $(r=0.901, p<0.001)$ の相関関係を認めた(図 2 )。一方，1 日水分摂取 量および塩分認知濃度は相関関係を認めず $(\mathrm{r}=$ $0.084, \mathrm{NS})$, さらに塩分摂取量と塩分認知濃度も, 相関関係を認めなかった（図 3 )。

DM-HD, DM-CAPD の水分摂取量と HbA1c ( $\mathrm{r}=-0.239, \mathrm{NS})$ および血糖值 $(\mathrm{r}=-0.288, \mathrm{NS})$ とは相関関係を認めなかった。同様に症例 T. Y. (男性 35 歳, インスリン療法患者) で透析前血糖 值と 1 日水分摂取量を検討すると，図 4 亿示すよ うに透析前血糖值は 75〜 $418 \mathrm{mg} / \mathrm{d} l$ と大きな変 動を認めたが，1 日水分摂取量とは相関関係を認 めなかった（ $\mathrm{r}=0.156, \mathrm{NS})$.

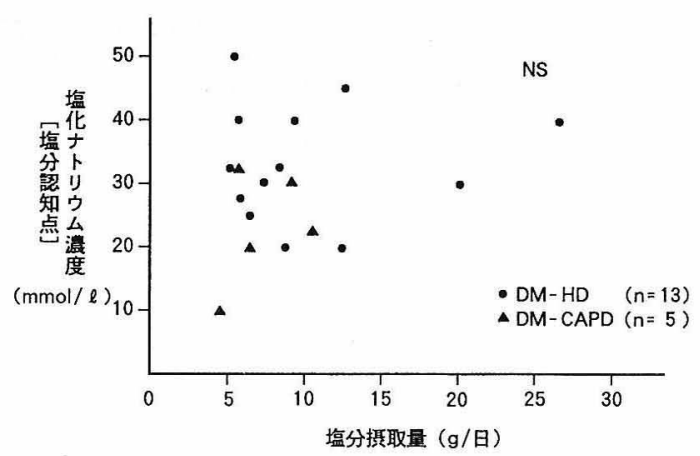

図 3 糖尿病性腎不全透析患者の塩分提取量と味 覚検査での塩分認知点

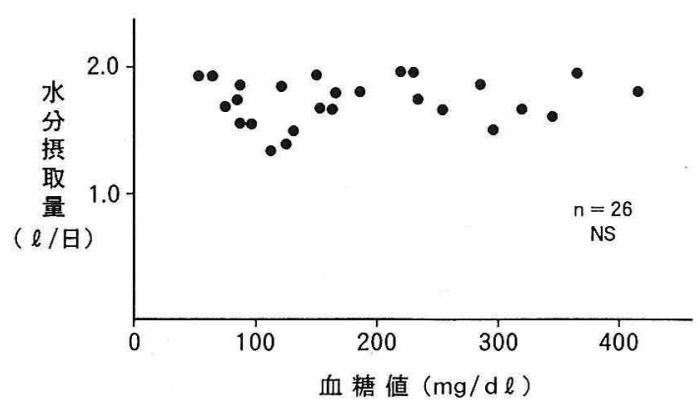

図 4 血液透析前血糖值と水分摄取量との関係 （症例 T. Y. 男性 35 歳, 糖尿病性腎不全, インスリン療法)

\section{考察}

透析患者では，健常人に比較し味覚障害が高度 であることはすでに知られている事実であ る ${ }^{1 \sim 4)}$ 。これは uremic neuropathy との関連性 ${ }^{2)}$, medium sized toxic catabolic molecules ह味覚 障害の関与, $Z n$ 代謝の関与7,8), 味蕾細胞の障害, $\mathrm{Ca}$ 拮抗薬およびビタミン $\mathrm{D}$ 製剤の影響9)など報 告されている.

味覚検査方法には電気味覚検查, 濾紙ディスク 法, 全口腔法, 舌滴下法がある。今回我々は糖尿 病性腎不全透析患者の塩分味覚障害を検討するに あたり，全口腔法を用いて行った。その理由は， 他の検査方法では舌のある領域を刺激するが，全 口腔法では口腔内のすべての味覚受容器が刺激さ れ，食物を摂取する場合と同様に考えられるから である。 
表 糖尿病性腎不全透析患者の味党障害と塩分找取量からみた患者特性と食事指導法

\begin{tabular}{|c|c|c|c|c|}
\hline 分類 & 塩分味覚認知 & 塩分掑取量 & 患者特性 & 食事指導法 \\
\hline a & 良好 & 少 & 良好な節制者 & $\begin{array}{l}\text { 塩分摄取量は現状通りで続け } \\
\text { るよう指導 }\end{array}$ \\
\hline $\mathrm{b}$ & 良好 & 多 & $\begin{array}{l}\text { 塩味を感じていても塩分を必 } \\
\text { 要以上に摄取してしまう }\end{array}$ & $\begin{array}{l}\text { うす味でも十分塩分を感じる } \\
\text { のだから塩分量を減らし食習 } \\
\text { 慣を変えるように指導 }\end{array}$ \\
\hline c & 不良 & 少 & $\begin{array}{l}\text { 減塩に詨する意識もあるが, } \\
\text { 味賞障害が強く, 味が良くわ } \\
\text { からいた自に摂取塩分 } \\
\text { 量が少なくなっている }\end{array}$ & $\begin{array}{l}\text { 塩味を感じるようでは塩分摂 } \\
\text { 取量が多い証拠となるで注 } \\
\text { 意するよう指導 }\end{array}$ \\
\hline $\mathrm{d}$ & 不良 & 多 & $\begin{array}{l}\text { 味覚障害が強く塩分摂取量が } \\
\text { 多くなっている }\end{array}$ & $\begin{array}{l}\text { 自分の塩分味賞が満足できる } \\
\text { 味付けでは, 塩分攝取過多と } \\
\text { なるので注意するよう指導 }\end{array}$ \\
\hline
\end{tabular}

糖尿病性腎不全透析患者では，非糖尿病透析患 者に比較し味覚感知濃度, 塩分認知濃度とも, 有 意に悪く塩分味覚障害が強いことが明らかとなっ た. 山田ら ${ }^{10)}$ の非透析の糖尿病患者に対する濾紙 ディスク法による味覚異常の報告では味覚認知度 は悪く，細小血管障害合併症例ではさらに悪いと している。このため糖尿病透析患者では，透析療 法による味覚異常に加え，糖尿病自体による味覚 異常が相加されているものと考えられた。

血中亜鉛濃度に関しては，糖尿病例と非糖尿病 例で明らかな差は認めなかった。このことより， 糖尿病例では非糖尿病例に比較し塩分味覚障害は 明らかに悪いが，血中亜鉛濃度レベルがその原因 になっているとは考えられなかった。

糖尿病性腎不全透析患者の 1 日の水分摂取量と 塩分摂取量は，有意の相関関係を認めた。そこで， 糖尿病性腎不全透析患者の水分摄取量と塩分認知 濃度の関連性を検討すると,これらの間には相関 を認めなかった。また，塩分摂取量と塩分認知濃 度にも相関は認めなかった。このことより, 塩分 味覚障害の程度と塩分, 水分摂取の遵守度加ら患 者像を分類すると, 次の 4 つに分けられると考え られた。すなわち a）塩分味賞認知良好で塩分 捸取量が少なく水分摄取量も少ない患者，b）塩 分味覚良好だが塩分提取量が多く水分攝取量も多 い患者，c）塩分味覚認知不良だが塩分摂取量は 少なく水分提取量も少ない患者，d）塩分味覚認 知不良で塩分捸取量が多く水分摂取量も多い患者 であり，このような味覚障害と塩分摄取量からみ
た患者特性と，これに対する食事指導法は表に示 す通りと考えられた。さらに，塩分管理不良とな る原因は味覚障害のためだけではなく，患者個々 の塩分 (塩味) への満足度の違いや，長年に渡る 食生活により形成された食習慣, 強いては減塩に 対する心構えや，自己管理能力の違いなどが関係 しているものと考えられた。

また，糖尿病透析患者の水分摂取量と $\mathrm{HbAlc}$ は相関を認めず，さらに HD 前血糖値と水分摂取 量も相関を認めなかった。症例 T. Y. を経時的に 観察した結果からも, 飲水量と血糖值との関連性 を見い出せなかった。このことより，糖尿病透析 患者の飲水量は，血糖コントロールよりも塩分摂 取量により規定されるものと考えられた。

以上より，糖尿病透析患者に扔いてそれぞれの 塩分味覚障害の程度を把握し，これを実際の塩分 攝取量と照らし合わせることにより，患者の塩分 摂取特性を理解することが可能となり，食事指導 の上で極めて有意義と考えられた。

\section{結論}

糖尿病性腎不全透析患者の味覚障害と塩分水分 管理につき検討し，以下の結論を得た。

1。糖尿病透析患者では，塩分味覚が非糖尿病 透析患者より有意に悪かった。

2 . 塩分認知濃度と塩分摂取量は相関を認めず, 味覚障害が必ずしも塩分恸取量の過剩に結びつく とは限らないと考えられた。

3. 糖尿病透析患者の水分摂取量は塩分摂取量 の多少により規定され，血糖コントロールの影響 
は少ないことが示唆された。

4. 塩分味覚障害の程度と実際の塩分摂取量を 対比させることにより, 患者の塩分摂取特性を把 握することが可能となり，食事指導上の意義が大 きいと考えられた。

\section{文献}

1) 薄井哲哉, 藤井まさ子：透析患者の味覚異常に ついて。腎と透析 $15 ： 435-438 ， 1983$

2) 坂本健一, 里中永一, 南條輝志男, 宮村 敬: 味賞障害を合併した患者の透析食. 臨牀透析 3：2019-2022，1987

3）佐々木環，佐藤哲也，山田昌彦，北野裕一，唐 井万里子, 松谷拓郎, 橋本 淳, 野村伸介, 新 開洋一, 平野 宏, 大沢源吾, 藤田浩志, 市川 和子：CAPD 患者の味賞障害と食欲. 臨牀透析 4:289-292, 1988

4) Burge JC, Park H, Whitlock CP, Schemmel RA: Taste acuity in patients undergoing long-term hemodialysis. Kidney Int 15:4953, 1979
5）木村玄次郎：血液透析患者の食事摄取量の評 価. 臨牀透析 2：1831-1840，1986

6）阿部 裕監修：ベットサイドの輸液療法. p 99101, 金芳堂, 京都, 1992

7) Mahajan SK, Prasad AS, Lambujon J, Abbasi AA, Briggs WA, Mcdonald FD : Improvement of uremic hypogeusia by zinc : a doubleblind study. Am J Clin Nutr 33 : 1517-1521, 1980

8) Atkin-Thor E, Goddard BW, O'Nion J, Stephen RL, Kolff WJ : Hypogeusia and zinc depletion in chronic dialysis patients. Am J Clin Nutr 31 : 1948-1951, 1978

9）中間淳子, 平良 悟, 宮部藤十郎, 西尾正一, 岸口 繁：透析患者の味覚障害 その因子の検 討. 大阪透析研究会誌 $11: 225-229,1993$

10）山田 尚, 鬼頭陽子, 板津武晴, 石黒泰男, 北 川祐子, 桜井た尃：糖尿病患者における味覚異 常判定試験としての濾紙ディスク法の臨床的意 義。栄養学雑誌 $42: 235-240,1984$ 